\title{
OPEN Description of five new species of the Madagascan flagship plant genus Ravenala (Strelitziaceae)
}

\author{
Thomas Haevermans ${ }^{1 凶}$, Annette Hladik ${ }^{2}$, Claude-Marcel Hladik ${ }^{2}$, Jacqueline Razanatsoa ${ }^{3}$,
} Agathe Haevermans ${ }^{1}$, Vololoniaina Jeannoda ${ }^{4} \&$ Patrick Blanc ${ }^{5}$

Madagascar's emblematic traveller's tree is a monospecific genus within Strelitziaceae, the family of the South African bird of paradise. Until now, this endemic genus consisted of a single species: Ravenala madagascariensis Sonn., which is grown everywhere in the tropics as an ornamental plant. The plant is immediately recognizable for its huge fan-forming banana-like leaves and is locally referred to in Magagascar by several vernacular names. "Variants" have been mentioned in the literature, but without any attempt to recognize formal taxa based on diagnostic features. In this paper, we formally describe five new species and fix the application of the name $R$. madagascariensis to the populations growing on the eastern coast of Madagascar, with the epitype growing in the marshy Fort-Dauphin area in the south. This paper has numerous implications for conservation biology and other domains of life sciences, due to the importance of this genus for the conservation of Madagascan ecosystems, the ornamental plant trade, as well as for its invasive status in several tropical areas.

Ravenala Adans. ${ }^{1}$, the traveller's palm or traveller's tree (l'Arbre du Voyageur in French, ravinala in Malagasy), is a member of the Strelitziaceae, a family within Zingiberales order whose evolutionary history is still not completely understood ${ }^{2}$. Strelitzia Banks ${ }^{3}$, the most species-rich genus in the family, has received considerably more attention than the other two monotypic genera Phenakospermum Endl. ${ }^{4}$ and Ravenala. Synflorescences of Ravenala are distichous and monopodial, and possess a stiff basal bract enclosing 5-20 successive bracts, each one encasing a contracted monochasium (a cincinnus); the synflorescence is itself sometimes complemented by a basal leaf-like bract. Each element of the cincinnii comprises a petal-like bracteole encasing a single flower along with the remaining of the cincinnus, each flower being perfectly hermaphroditic and not varying with their position on the inflorescence. The flower structure of Ravenala has been interpreted variously in the literature, Perrier ${ }^{5}$ describing it as similar to a Musa L. flower with five true segments. However, the perianth is more aptly described as consisting of three petaloid sepals and three petals ${ }^{6}$ (two fused sheathing the immature stamens which mechanically need to be freed to liberate the anthers, and one free petal, whose morphological characteristics are of taxonomic importance for distinguishing the various species). The flowers contain six free stamens and a style that is roughly as long as the perianth. The fruit is a dehiscent dry woody trilocular capsule, the shape of the outer parts being of taxonomic significance. Ravenala seeds are attached to a fatty aril which has a distinctive bright ultramarine blue color (varying from deep ultramarine blue to sky blue depending on the maturity), which contrasts with the orange aril found in the other genera of Strelitziaceae (the South American endemic Phenakospermum and the South African Strelitzia). The adaptive significance of this difference may be linked to the dispersers of the seeds, the bright orange aril being documented as an adaptation to bird dispersal, while the blue color can be an adaptation to mammal dispersal. Studies have mentioned that some lemurs see only blue and green ${ }^{7-9}$, or have linked the bright blue aril of Ravenala to the fact that perception of this color has been maintained by evolution in some Madagascan nocturnal lemurs such as aye-ayes ${ }^{10}$. However, Kress ${ }^{11}$ has also described Ravenala seed dispersal by birds. The morphological and ecological heterogeneity of wild Ravenala has been mentioned in several studies ${ }^{12-15}$, which were the first to consider scientifically these morphological

${ }^{1}$ Institut de Systématique Évolution Biodiversité (ISYEB), Muséum National d'Histoire Naturelle, Centre National de la Recherche Scientifique, École Pratique des Hautes Études, Université des Antilles, Sorbonne Université, 45 Rue Buffon, CP 50, 75005 Paris, France. '2Muséum National d'Histoire Naturelle, 57 rue Cuvier, 75005 Paris, France. ${ }^{3}$ Parc Botanique et Zoologique de Tsimbazaza, Antananarivo 101, Madagascar. ${ }^{4}$ Département de Biologie et Écologie Végétale, Université d'Antananarivo, Faculté des Sciences, Antananarivo 101, Madagascar. ${ }^{5}$ Centre National de la Recherche Scientifique (CNRS), 3 Rue Michel-Ange, Paris, France. ${ }^{\circledR}$ email: thomas.haevermans@ mnhn.fr 

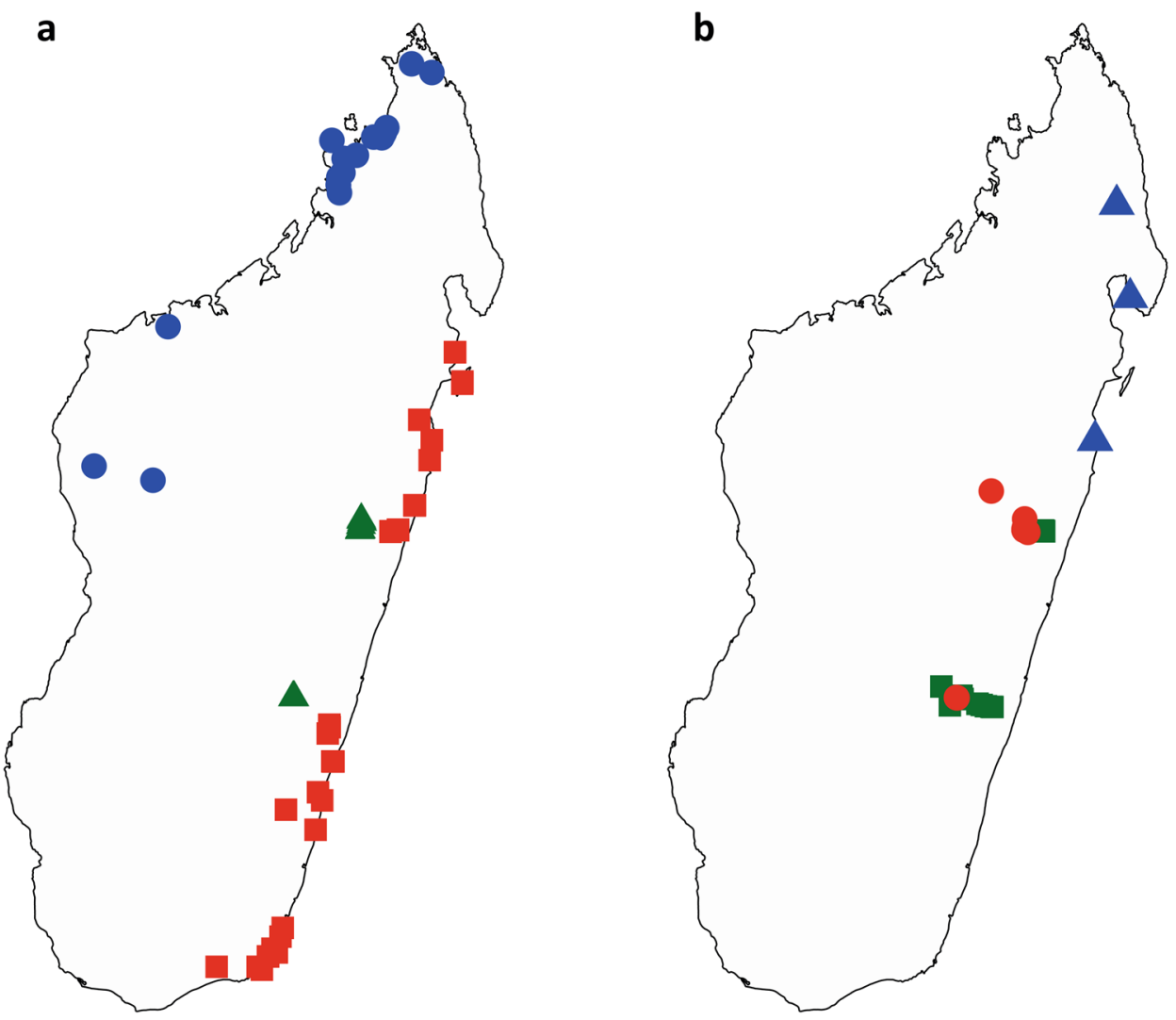

Figure 1. Distribution of identified specimens and observations of genus Ravenala in Madagascar. (a) $R$. agatheae (blue), R. hladikorum (green), and R. madagascariensis (red). (b) R. blancii (red), R. grandis (green), and $R$. menahirana (blue). Maps generated using R version 4.0 .5 (https://www.r-project.org/) and Rstudio version 1.3.1093 (https://www.rstudio.com/) softwares.

variations. One of the differences highlighted is the seemingly variable suckering ability of Ravenala. This genus is usually represented as a tall suckering plant with leaves forming a perfect fan, and this can easily be appreciated from the many cultivated specimens throughout the world. However, some native Malagasy variants of the genus appear consistently devoid of suckers ${ }^{13}$, even when cultivated ex situ, while others consistently form suckers. Producing basal suckers is regarded by Tomlinson ${ }^{16}$ as a feature of the order Zingiberales, with the genus Ensete Bruce ex Horan. ${ }^{17}$ being the sole exception (bud neoformation can be artificially triggered in Ensete ${ }^{18}$ after removal of the main bud, but this is not true "suckering" from existing dormant buds). Solitary (non-suckering) Ravenala taxa are thus another exception in presenting a monocaulous monopodial architecture (Corner model ${ }^{19}$ ) within a suckering order (Tomlinson model ${ }^{19}$ ).

\section{Results}

Several morphotypes within Ravenala have been observed throughout Madagascar ${ }^{12-15}$, but the taxonomic study of this genus had always been impaired by the extreme difficulty of collecting these enormous plants plus the added difficulty accessing most areas in Madagascar, leading to a paucity of adequate specimens in natural history collections. Our own field and herbarium specimen observations of the various morphotypes led us to recognize and distinguish six stable units defined by observable characteristics (i.e. species), consisting of five new species in addition to Ravenala madagascariensis. Thus, the total number of species recognized in Ravenala is now similar to the number of species in its sister genus Strelitzia ${ }^{2}$ from southern Africa. Although the large Strelitzia species are difficult to distinguish when not in flower, Ravenala species can be identified when not flowering as the characters we used to define our species are observable at different developmental stages (young plants, nonfertile adults, flowering and fruiting plants, distinct flowering periods). While the distribution of the genus in Madagascar and the exact location of our type specimens can be mapped (Fig. 1), the exact extent of occurrence of each species is difficult to assess due to the aforementioned lack of available specimens. For example, in the Manombo area (eastern Madagascar), two variants are listed (the single-trunked tokam-pototra and the suckering maroanaka $)^{20}$, but no specimens are available for scientific scrutiny to allow us to assign them to one of the taxa described here. One of the solitary morphotypes called malama from the Andasibe area (our R. blancii), may correspond to the variant called locally fontsy ala discovered ${ }^{21}$ in the Forest Reserve of Ranomafana (200 $\mathrm{km}$ to the south of Andasibe, at the same elevation range), but again we lack specimens to attest the presence of this taxon. This suggests that this peculiar malama variant could be present across a large part of the eastern coast of Madagascar, at elevations ranging from $600 \mathrm{~m}$ to $1,100 \mathrm{~m}^{12,20}$. All species except Ravenala agatheae 

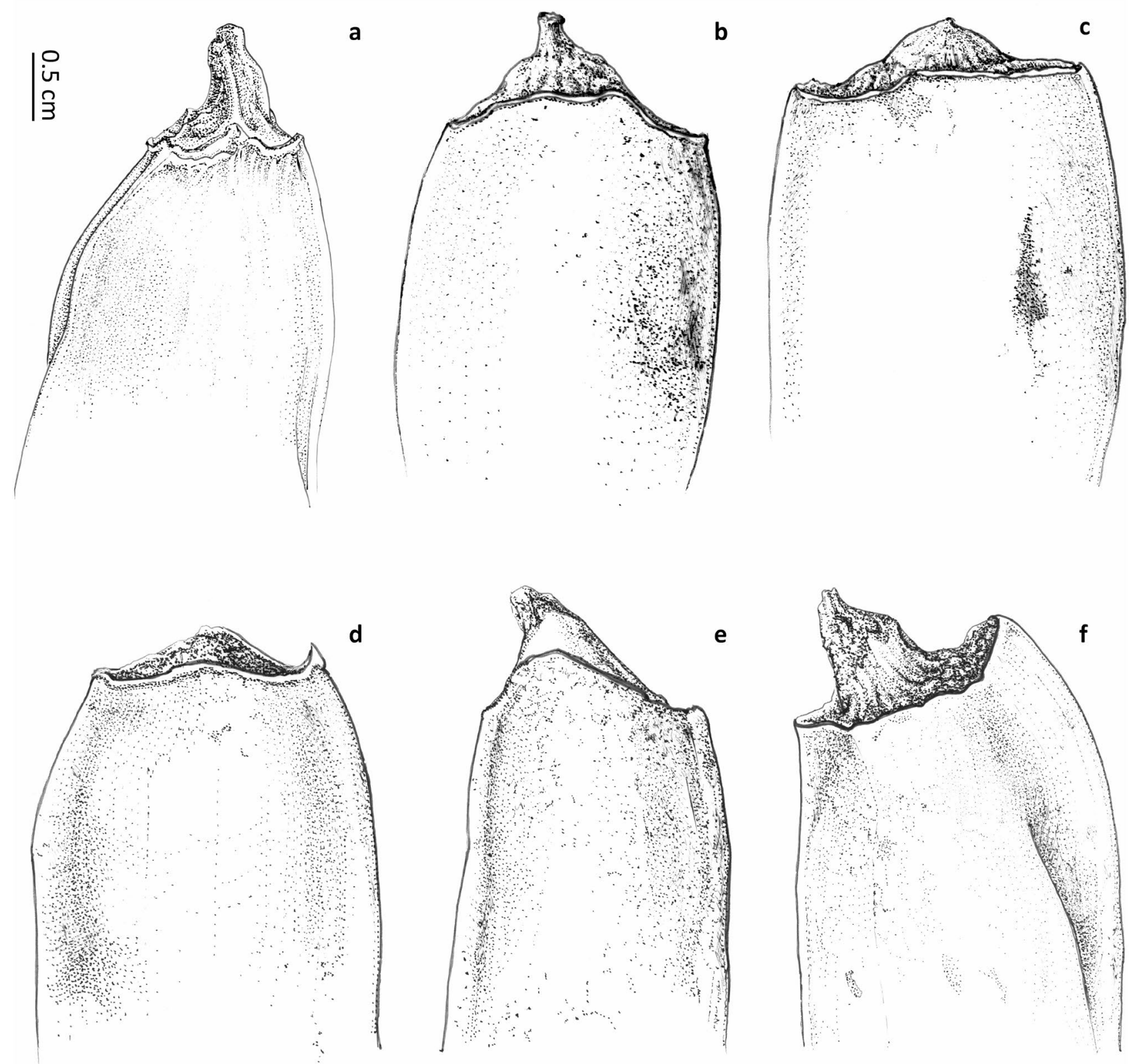

Figure 2. Comparison of non-opened fruit apices. (a) R. agatheae. (b) R. blancii. (c) R. hladikorum. (d) $R$. grandis. (e) $R$. madagascariensis. (f) $R$. menahirana. Ink drawings on $75 \mu$ polyester tracing paper by Agathe Haevermans@.

are distributed along the eastern coast of Madagascar (Fig. 1), and their distribution range seems to follow an elevation gradien $t^{20}$, with $R$. blancii and $R$. hladikorum being found at the highest elevations, $R$. grandis at midelevation, and $R$. madagascariensis and R. menahirana being found at sea level (of these, only R. madagascariensis appears to be distributed all along the coast). By contrast, Ravenala agatheae from the north-western part of Madagascar is not found elsewhere on the island (Fig. 1). The major traits used to distinguish these species, as detailed in the identification key and the taxonomic treatment, are: plants suckering or strictly solitary; the flowering period; traits pertaining to the petiole such as the presence of various papery appendages or color patterns; the inflorescences; the flower structure (especially the length of the free petal $v s$. the lentgh of the two fused petals); and shape and structure of the fruit apices (Fig. 2).

\section{Taxonomic treatment}

Generic name. Ravenala Adans. ${ }^{1}$ (1763: 67). EUrania Schreb. ${ }^{22}$ (1789: 212). -Ravenala Scop. ${ }^{23}$, nom. illeg. (1777: 96) as "Ravenalla Adans".

Type species Ravenala madagascariensis Sonn. ${ }^{24}$.

Note: Dorr \& Parkinson ${ }^{25}$ proposed to conserve the spelling Ravenala Scop. (and correct Scopoli's original orthography "Ravenalla") against Ravenala Adans. on the basis that Adanson's generic names (using a uninominal 
nomenclature for species) were invalid. Brummitt ${ }^{26}$ rejected this proposal and considered that Adanson's generic names were valid ${ }^{27}$ and thus that there was no need to use Scopoli's Ravenala (Ravenalla). Moreover, the exact wording in Scopoli ${ }^{23}$ (1777: 96) is "Ravenalla Adans.", citing Adanson explicitly, but with an incorrect spelling for the generic name (the double "l").

Typification and emended description. Ravenala madagascariensis Sonn. (1782: 2[ed. qto.]: 223, tt. 124-126).

$\equiv$ Ravenala madagascariensis J.F.Gmel. ${ }^{28}$ (1791: 567). EUrania madagascariensis (Sonn.) Schreb. ex Forsyth

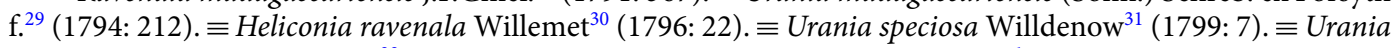
ravenalia (Willemet) A.Rich. ${ }^{32}$ (1831: 19). -Ravenala madagascariensis Adans. ${ }^{1}$ (1763: 597), nomen invalid., appearing on page 597, abbreviated in the final index of Adanson's book as "Ravenala madag. 67", which can also be construed as referring to Madagascar as a locality.

Type Lectotype, here designated: The plate numbered 126, representing the typical lax mature infructescence, in Sonnerat ${ }^{24}$ (1782: plate 126). Epitype, here designated: MADAGASCAR • Fort-Dauphin, Forêt de Manantantely,

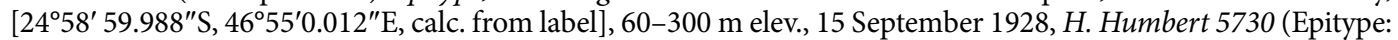
MNHN-P-P02234599!, Isoepitypes: MNHN-P-P02234602!, MNHN-P-P02234604!, MNHN-P-P02234605!).

Additional specimen examined: MADAGASCAR • Toamasina: Foulpointe, Analalava Forest, plant growing close to the main forest station, $17^{\circ} 42.3^{\prime} \mathrm{S}, 49^{\circ} 27.38^{\prime} \mathrm{E}, 50 \mathrm{~m}$ elev., 20 March 2016, T.Haevermans, M. Vorontsova, S. Dransfield \& J. Razanatsoa 821 (TAN!, P!, K!) • X. Aubriot et al. 45 (P00696168!, P00696167!, P00685124!, TAN!) - Along Route \#5 from Fenerive to Maroantsetra, disturbed areas along road, $100 \mathrm{~m}$ elev., 28 February 1975, T. B. Croat 32540 (L-WAG.1111446!, L-WAG.1111447!, MO-358490!, MO-358491!, MO-358523!) • Toalagnaro, Ebakika, District de Fort-Dauphin, 12 July 1932, R. Decary 10107 (P02234596!) • Vondrozo (commune de Farafangana), 16 September 1926, R. Decary 5428 (P02234588!, P02234591!, P02234592!) • 2 km E of Ranomafana towards Brickaville, $18.965^{\circ}$ S, $48.8564^{\circ}$ E, 4 March 1992, J. Kress et al. 92-3412 (US00424302!, US00424299!, US00424300!, US00424301!, US00424303!) • $18 \mathrm{~km} \mathrm{E} \mathrm{of} \mathrm{Ranomafana,} 25 \mathrm{~km} \mathrm{~W}$ of Brickaville, $18.9453^{\circ} \mathrm{S}$, 48.9664 E, 4 March 1992, J. Kress et al. 92-3414 (US00424312!, US00424309!, US00424310!, US00424311!, US00424313!). MAURITIUS • Isle de France, s.dat., Commerson s.n. (P02234587!, P-JU!, P-LAM!).

Identity of Ravenala madagascariensis Sonn. -Figs. 2d, 3d, 4d, 5d-In the absence of a specimen undoubtedly collected or seen by Sonnerat (Commerson's specimens, collected in Mauritius and preserved in both Jussieu's and Lamarck's herbaria at the Paris herbarium (P-JU and P-LAM), might actually be part of original material), we decided to lectotypify from plates 124,125 and 126 of the protologue in Sonnerat's valid publication ${ }^{24}$ of the species. On page 225, Sonnerat ${ }^{24}$ mentions that the plant originated from Madagascar but was transported and established in Mauritius (known at the time as Isle de France) at the "Jardin des Pamplemousses". We observed plants growing in this garden as well as naturalized plants occurring in the wild in Mauritius; all the plants we saw suckered and possessed the characteristic pointed conical fruits also observed in the Fort-Dauphin population. Sonnerat also specified that the original plant grew in marshy areas, which corresponds exactly to the coastal populations that can be found on the eastern coast of Madagascar (i.e. the "Horonorona" variant of Blanc et al. ${ }^{13}$ ). Plate 126 shows the typical mature infructescence of the species, with the space between bracts increasing before releasing the seeds (unlike other species of Ravenala). However, the "tree" pictured on plate 124 is a non-suckering plant, which in our opinion can be explained as artistic license on the part of the illustrator, as all the plants observed in Mauritius consistently sucker, like the plants growing in the south-eastern marshy areas. We also decided to designate an epitype with a documented locality in Madagascar (the material in P-JU and P-LAM does not bear a precise indication of locality) to fix the application of the name R. madagascariensis to the populations occurring in the marshy areas surrounding Fort-Dauphin, where only one morphotype is known.

Emended description Plants suckering, 6-12 meters tall (adult), trunk circumference (d.b.h.) $20-30 \mathrm{~cm}$, juvenile and adult laminae distributed in a perfect fan, 14-25 leaves simultaneously alive on the adult plant, 1-3 leaves between inflorescences. Leaves adult petiole 380-440 cm long, greenish-yellow, slightly waxy, sheath margin undeveloped to moderately developed (0-9 mm), entire, not drying, slightly splitting when aged (Fig. 3d), petiole/lamina ratio 1.9-(2.2)-2.3, adult lamina $200 \times 100 \mathrm{~cm}$, light green, juvenile lamina base non-decurrent. Inflorescences 4-6 live lateral inflorescences at a time, $100 \times 100 \mathrm{~cm}$ (peduncle excluded), $8-16$ bracts per inflorescence, bracts $200-450 \times 50-100 \mathrm{~mm}$, with some wax to very waxy, margin uniformly green (Fig. $4 \mathrm{~d}$ ), cincinnii of ca. 10 flowers per bract, flowering sequentially, bracteoles without a colored stripe. Flowers 240-280 mm long (ovary included), inferior ovary $40-50 \mathrm{~mm}$ long, perianth yellowish, sepals narrowly triangular 240-250 $\times 10-12 \mathrm{~mm}$, sheathing (fused) petals narrowly triangular $220-230 \times c a .10 \mathrm{~mm}$, free petal acicular $180-190 \times 5$ $\mathrm{mm}$, slightly smaller than the remaining perianth with mean free petal $/$ mean fused petal length ratio $=0.8$, petal blotches absent, stamens (roughly) the same size as the perianth, 200-210 mm long, style 200-230 $\mathrm{mm}$ long, stigma 15-20 mm long, oblong ovoid with a basal constriction. Infructescences lax (bract bases not imbricate at maturity), stiff and coriaceous persisting bracts, old infructescences deciduous, $4-8$ fruits per bract. Fruits $70-120$ $\times 30-35 \mathrm{~mm}$, trilocular septifragal capsule, apices conical (Fig. 2d), seeds 6-(8.5)-11 × 5-(6.4)-8 mm, shiny, dark brown, mostly globose, varying in shape according to their distribution in the capsule, ultramarine blue aril.

Ecology Ravenala madagascariensis is a low-altitude species restricted to swampy areas of the eastern coast of Madagascar. Populations outside of Madagascar on nearby islands are reputedly non-indigenous ${ }^{24}$.

Preliminary IUCN assessments We propose a Least Concern status for R. madagascariensis, having an E.O.O $>20,000 \mathrm{~km} 2$ and an A.O.O. $>2,000 \mathrm{~km} 2(\text { criterion B })^{33}$.

Note This emended description for R. madagascariensis was drawn up from our own observations and collections, and was made comparable point by point to the descriptions of the five new species presented below, along with a dichotomous identification key to all six species. 


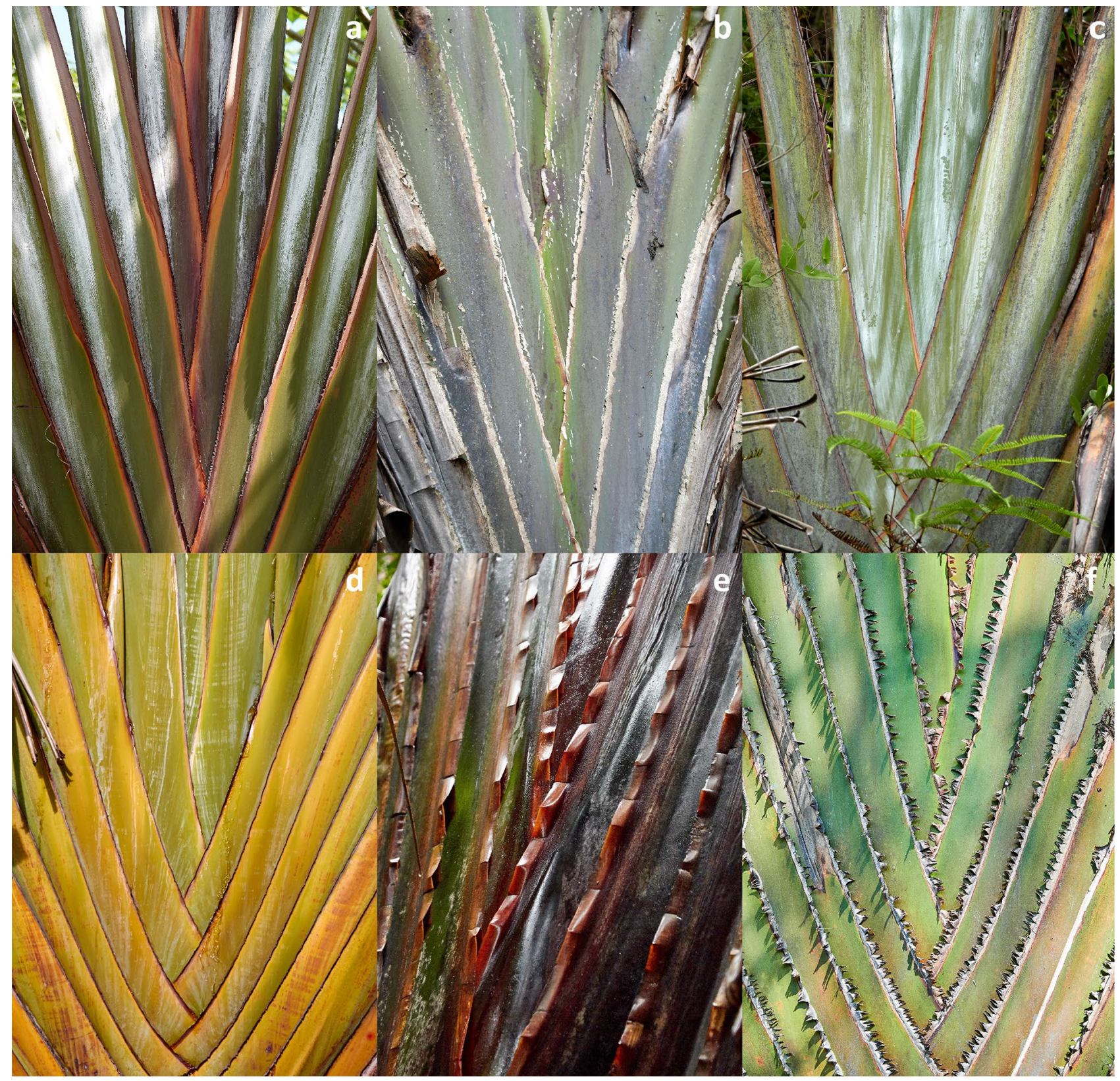

Figure 3. Comparison of petiole bases. (a) R. agatheae. (b) R. blancii. (c) R. grandis. (d) R. madagascariensis. (e) R. menahirana. (f) R. hladikorum. Photographs Thomas Haevermans@.

New species descriptions. Ravenala agatheae Haev. \& Razanats. sp. nov._Figs. $2 a, 3 a, 4 a, 5 a, 6$. Type MADAGASCAR • Antsiranana: Ambanja District, along R.N.6 road to Ankaramibe, $13^{\circ} 45^{\prime} 54.8^{\prime \prime} \mathrm{S}, 48^{\circ} 21^{\prime} 27.7^{\prime \prime} \mathrm{E}$, $30 \mathrm{~m}$ elev., on degraded lateritic slopes, 28 October 2018, T. Haevermans, A. Haevermans \& J. Razanatsoa 830 (Holotype: TAN!, Isotypes: K!, MO!, P!).

Paratypes MADAGASCAR • Antsiranana: 57-58 km N of Ambanja, 1322'59.9"S, 48² $48^{\prime} \mathrm{E}, 22$ May 1974, A.H. Gentry 11878 (L-WAG.1111448!, L-WAG.1111449!, MO-358489!, TAN) • Ampasindava, forêts d'Ambilanivy et Rangoty, 134ㅇ'36"S, 48 10'48"E, 29 November 2007, L. Nusbaumer 2658 (G334213/1!, MO!, TAN) • Mahajanga: Morafenobe, Beravy, $15 \mathrm{~km}$ from Beravy, near the road from Orombato to Beravy, $18^{\circ} 3^{\prime} 50^{\prime \prime} \mathrm{S}, 44^{\circ} 31^{\prime} 46^{\prime \prime} \mathrm{E}, 09$ June 2016, F. Rakotonasolo et al. 2772 (K, P00782931!, TAN).

Diagnosis Similar to Ravenala madagascariensis but differs in its dark green narrower laminae, tricolor petioles with very developed dryish petiole sheath margins, very waxy petioles, the persistence of older infructescences for several years, a purple stripe on the bract margin, longer bracts, a whitish perianth, brown blotches on its mature fused petals, the bracteole apex tinged with pink, an ovoid pointed stigma, dense infructescences, smaller inflorescences, the free petal much shorter than the fused petals, and an end of year flowering period.

Distribution Plants restricted to Madagascar, growing in the north-western part of the island. We observed it growing from the southern part of the Diego Suarez area (on the hills along the road leading to Tsingy Rouge 


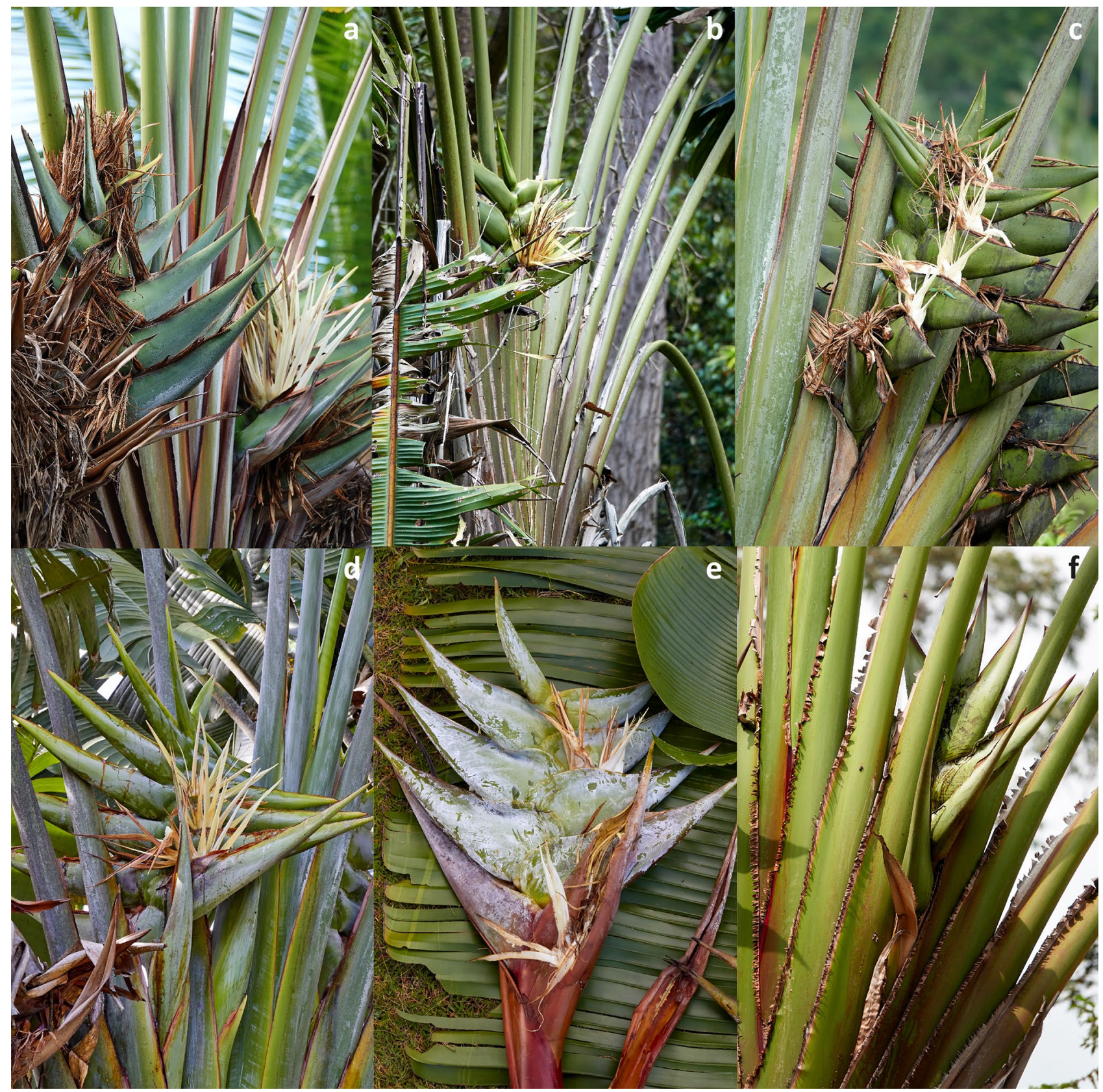

Figure 4. Comparison of inflorescences. (a) R. agatheae. (b) R. blancii. (c) R. grandis. (d) R. madagascariensis. (e) R. menahirana. (f) R. hladikorum. Photographs Thomas Haevermans@.

and the city of Sadjoavato) in the north to the western part of the Mahajanga province down to the Melaky region, with most observations around Ambanja ${ }^{34}$. We also observed that the species was cultivated on Nosy Be.

Preliminary IUCN assessments We propose a Least Concern status for R. agatheae, having an E.O.O $>20,000 \mathrm{~km} 2$ and an A.O.O. $>2,000 \mathrm{~km} 2$ (criterion B) $)^{33}$.

Ecology This species is adapted to seasonally dry and warm coastal habitats, growing on slopes at low elevations in north-western coastal areas of Madagascar, from Antsiranana (Diego-Suarez) down to the Melaky region in the Mahajanga province.

Etymology This species is named after to the first author's wife, Agathe Haevermans, a botanical illustrator at the Muséum National d'Histoire Naturelle, who helped discover this species in the field with the collecting team and who contributes greatly to botany by producing illustrations of new taxa from biodiversity hotspots such as Madagascar.

Description Plants suckering, 6-10 meters tall (adult), trunk circumference (d.b.h.) $20-30 \mathrm{~cm}$, juvenile and adult laminae distributed like a regular fan, 9-22 leaves simultaneously alive on the adult plant, 1-3 leaves between inflorescences. Leaves adult petiole 300-460 cm long, tricolor (dark green with a waxy white strip and red petiole sheath margin subsequently drying out, Fig. 3a), very waxy, sheath margin very developed (10 $\mathrm{mm}$ and more), entire, dryish-papyraceous and protruding at 90 degrees, petiole/lamina ratio 1.7-(1.95)-2.2, adult 


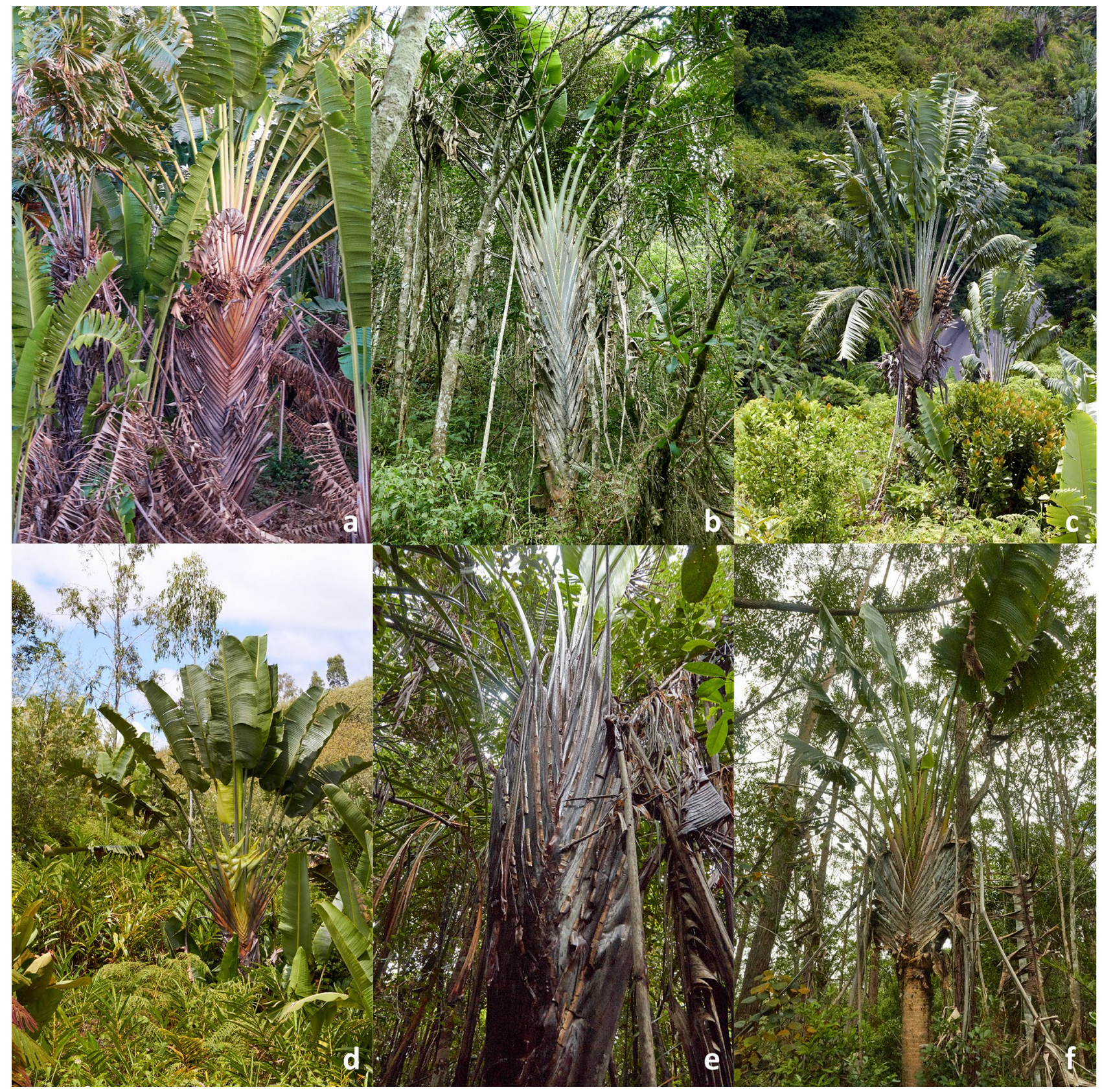

Figure 5. Species of Ravenala in their natural habitat. (a) R. agatheae. (b) R. blancii. (c) R. grandis. (d) $R$. madagascariensis. (e) R. menahirana. (f) R. hladikorum. Photographs Thomas Haevermans@.

lamina $174-210 \times 72-86 \mathrm{~cm}$, dark green, juvenile lamina base non-decurrent. Inflorescences $4-6$ live lateral inflorescences at a time, $70-90 \times 90-100 \mathrm{~cm}$ (peduncle excluded), 10-14 bracts per inflorescence, bracts 450-500 $\times 80-90 \mathrm{~mm}$, with some waxiness (Fig. 4a), margin bearing a purple stripe, cincinnii of 8-10 flowers per bract, flowering sequentially, some pink tinge at the apex of bracteoles. Flowers $260-310 \mathrm{~mm}$ long (ovary included), inferior ovary 40-60 mm long, perianth whitish, sepals narrowly triangular 220-250×ca. $10 \mathrm{~mm}$, sheathing (fused) petals narrowly triangular 200-220 $\times c a .10 \mathrm{~mm}$, free petal acicular 130-140 $\times 5 \mathrm{~mm}$, much smaller than the remaining perianth with a mean free petal / mean fused petal length ratio $=0.6$, petal blotches present, stamens (roughly) the same size as the perianth, 210-220 mm long, style $220 \mathrm{~mm}$ long, stigma $15 \mathrm{~mm}$ long, ovoid-pointed with basal constriction. Infructescences compact (bracts bases imbricate at all stages of maturity), stiff and coriaceous persisting bracts on mature infructescence, persistence of old infructescences, 4-10 fruits per bract. Fruits 90-110 ×30-45 mm, trilocular septifragal capsule, apices conical (Fig. 2a), seeds shiny, dark brown, mostly globose, varying in shape according to their distribution in the capsule, ultramarine blue aril.

Ravenala blancii Haev., V. Jeannoda \& A. Hladik sp. nov. -Figs. 2b, 3b, 4b, 5b, 7. Type MADAGASCAR • Andasibe; $18^{\circ} 56^{\prime} 00^{\prime \prime} \mathrm{S}, 48^{\circ} 25^{\prime} 06^{\prime \prime} \mathrm{E}$; $940 \mathrm{~m}$ elev.; 01 December 2002; A. Hladik \& C.-M. Hladik 6760 (Holotype: TAN!, Isotypes: K!, MO!, P!). 


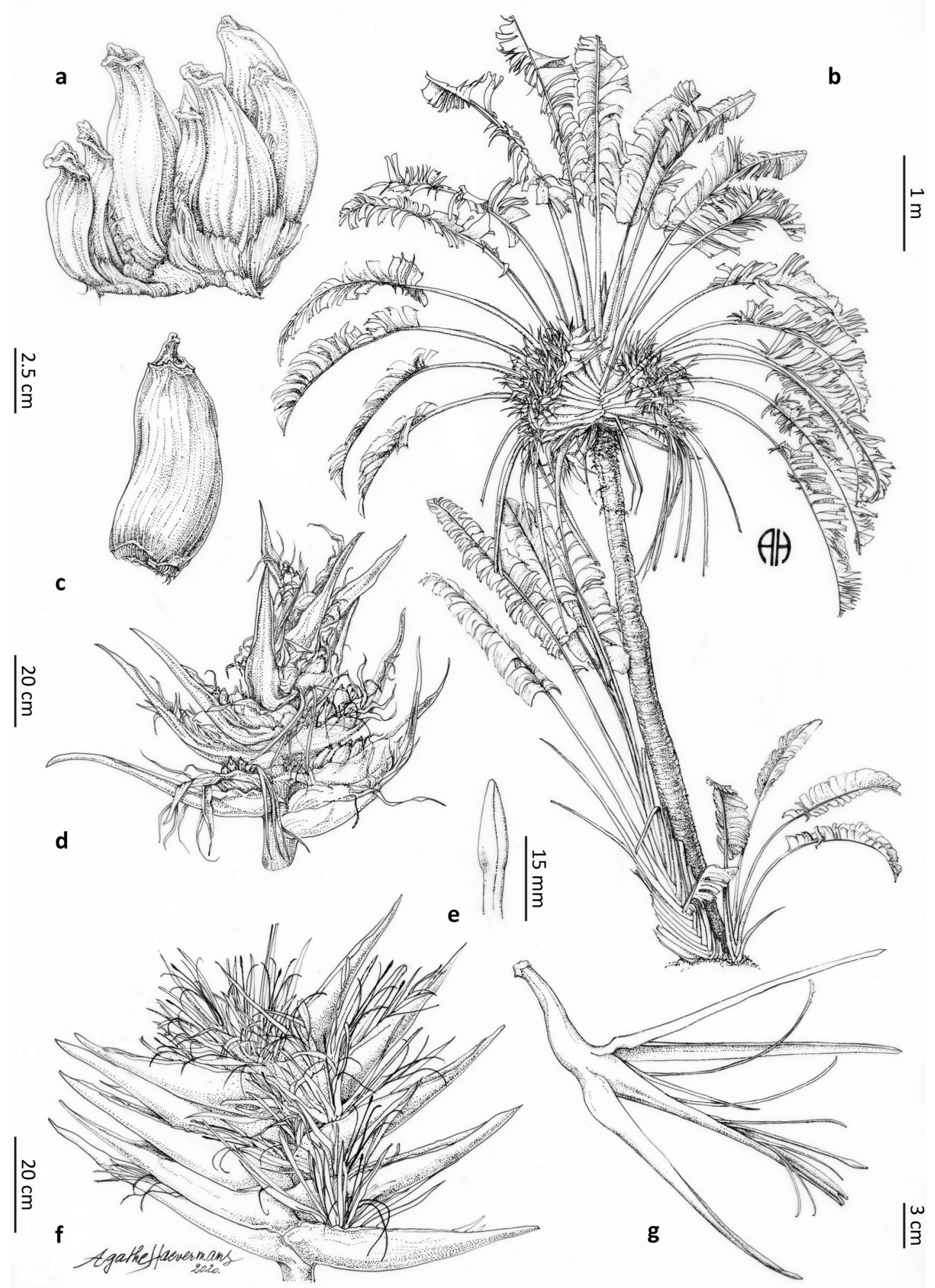

Figure 6. Ravenala agatheae. (a) young infructescence. (b) adult plant habit showing the suckers at the base and the persistent petioles and old infructescences. (c) fruit with a conical apex. (d) infructescence with remains of dried flowers and dried bracts. (e) style apex. (f) inflorescence with open flowers. (g) open flower. Ink drawings on $75 \mu$ polyester tracing paper by Agathe Haevermans $@$ from specimen Haevermans et al. 830, and observations in-situ. 


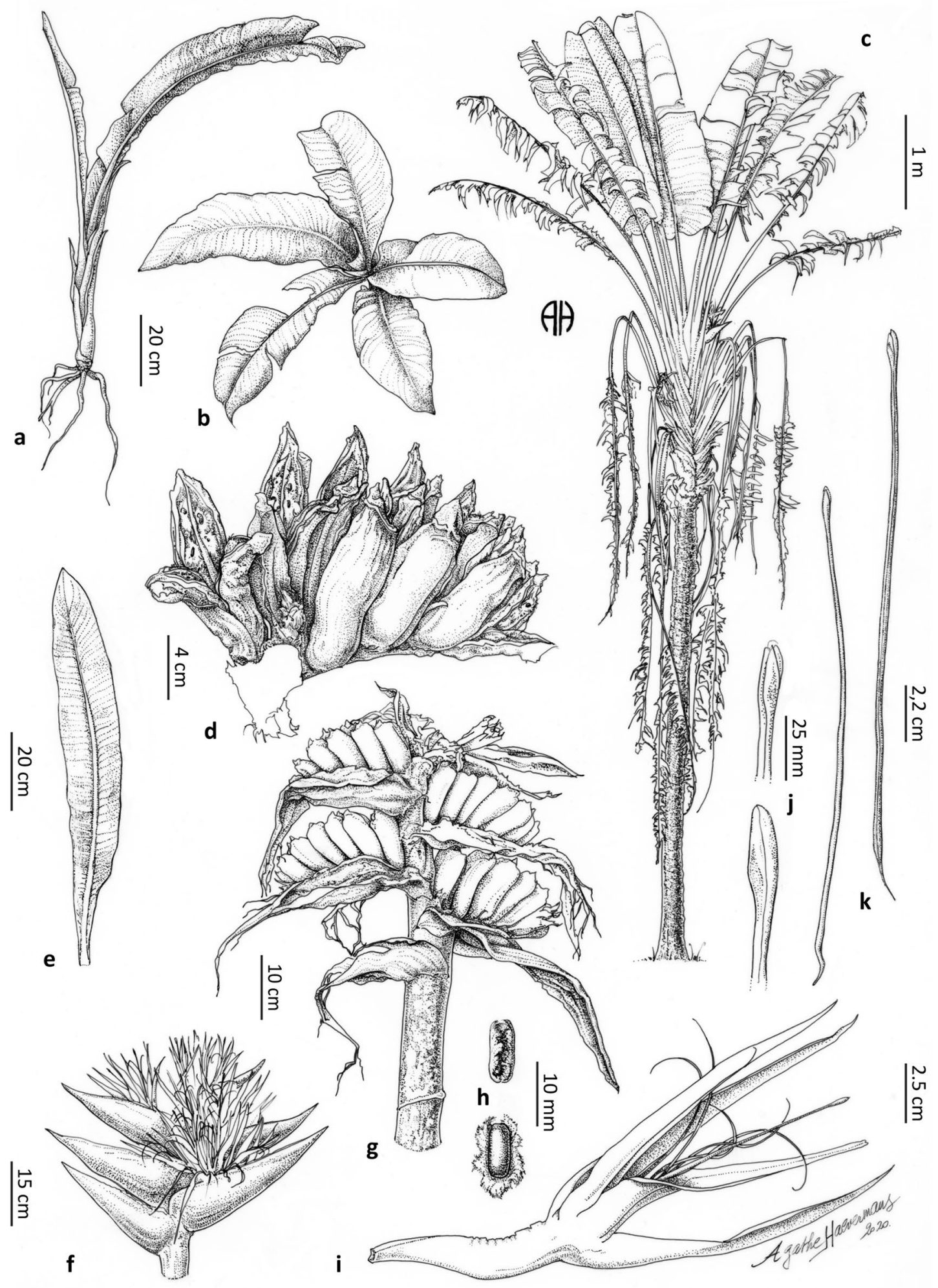

Figure 7. Ravenala blancii. (a) juvenile plant habit with roots. (b) juvenile plant showing the arrangement of laminae. (c) adult plant habit. (d) mature infructescence segment. (e) juvenile leaf showing the attenuate base of the lamina. (f) inflorescence with sub-simultaneous opening of the flowers. (g) young infructescence with already degraded bracts. (h) seeds with arilla. (i) open flower. (j) details of the stigma. (k) style. Ink drawings on $75 \mu$ polyester tracing paper by Agathe Haevermans@ from specimens Hladik 6790, 6239, 6650, Haevermans et al. 832, and observations in-situ. 
Paratypes MADAGASCAR • Andasibe; 1856'00"S, 48²5'06"E; 940 m elev., 23 Aug. 1998, A. Hladik \& al. 6239 (P!, fruits) • June 2001, A. Hladik \& al. 6650 (P!, leaves, fruits, bracts) • Andasibe-Mantadia area, Vakôna, Kalonora; $18^{\circ} 53^{\prime} 17.3^{\prime \prime} \mathrm{S}, 48^{\circ} 25^{\prime} 51.3^{\prime \prime} \mathrm{E}, 08$ November 2018, $934 \mathrm{~m}$ elev., T. Haevermans \& al. 832 (K!, MO!, P!, TAN!).

Diagnosis Similar to Ravenala madagascariensis but differs in its non-suckering habit, decurrent juvenile lamina bases, toroidal distribution of juvenile laminae, smaller number of leaves simultaneously alive on the adult plant, dark green lamina and green non waxy petiole, smaller leaves, smaller number of live inflorescences, smaller number of bracts in an inflorescence, non-waxy bracts, sub-simultaneous flowering, smaller flowers, smaller inflorescences, non-persistence of entire bracts on dry infructescences, October/November flowering period.

Distribution Andasibe-Mantadia, Ranomafana ${ }^{21}$. Restricted to Madagascar.

Preliminary IUCN assessments We propose a Data Deficient status for R. blancii; further fieldwork is required to understand its precise distribution and the status of its populations ${ }^{33}$.

Ecology High-elevation species found in eastern rainforests at elevations between 600 and 1,100 m. The species seems to favor cool tropical humid and shady conditions.

Etymology This species is named after Dr. Patrick Blanc, world renowned botanist, plant ecologist and street artist, inventor of the planted vertical walls known as "Mur Végétal" and who first recognized the sheer originality of the juvenile phases of this peculiar taxon.

Description Plants solitary (never suckering), 10-15 meters tall (adult), trunk circumference (d.b.h.) 20-30 $\mathrm{cm}$, juvenile laminae distributed in a toroidal shape, adult laminae arranged in a regular fan, 9-16 leaves simultaneously alive on the adult plant, 2-4 leaves between inflorescences. Leaves adult petiole $240-310 \mathrm{~cm}$ long, green, not waxy, sheath margin undeveloped, entire, not drying, smooth with a worn-out irregular aspect (Fig. 3b), petiole/lamina ratio 1.8-(2.0)-2.2, adult lamina 120-160 ×90-104 cm, dark green, juvenile lamina base decurrent. Inflorescences 2-3 live lateral inflorescences at a time, $60 \times 70 \mathrm{~cm}$ (peduncle excluded), 4-6 bracts per inflorescence, bracts 160-350 $\times 50-90 \mathrm{~mm}$, no waxiness (Fig. 4b), margin color uniformly green, cincinnii of 5-14 flowers per bract, flowering sub-simultaneously, bracteoles sometimes pink colored. Flowers 165-280 mm long (ovary included), inferior ovary 40-50 mm long, perianth whitish-yellowish, sepals narrowly triangular $125-231 \times 10-12 \mathrm{~mm}$, sheathing (fused) petals narrowly triangular 105-190 $\times 10 \mathrm{~mm}$, free petal acicular 105-178 $\times 3-5 \mathrm{~mm}$, free petal and fused petals of sub-equal size with a mean free petal $/$ mean fused petal length ratio $=$ 1.0, petal blotches absent or present, stamens (roughly) the same size as the perianth, 115-186 mm long, style 132-220 mm long, stigma 20-25 mm long, ovoid to ovoid-pointed with a basal constriction. Infructescences compact (bract bases imbricate at all stages of maturity), torn and degraded bracts on mature infructescence, old infructescences deciduous, 5-14 fruits per bract. Fruits $80-120 \times 32-45 \mathrm{~mm}$, trilocular septifragal capsule, apices conical (Fig. 2 b), seeds 6-10 $\times 3.2-6 \mathrm{~mm}$, shiny, dark brown, mostly globose, varying in shape according to their distribution in the capsule, ultramarine blue aril.

Note The strong leaf dimorphism between juvenile and adult forms is characteristic of this species ${ }^{13}$, a phenomenon which is not present in the other taxa. The base of the juvenile plant usually grows buried in the leaf litter due to the action of traction roots ${ }^{13}$, its decurrent leaves (Fig. 7) giving it the aspect of a bird's nest fern.

Ravenala grandis Haev., Razanats., A. Hladik \& P. Blanc sp. nov.-Figs. 2c, 3c, 4c, 5c. Type. MADAGASCAR - Ampasimbe Commune, Maromaniry Fokontany, along Route Nationale, 18 $8^{\circ} 57^{\prime} 41.8^{\prime \prime} \mathrm{S}, 48^{\circ} 42^{\prime} 41.4^{\prime \prime} \mathrm{E}, 258 \mathrm{~m}$ elev., 08 November 2018, T. Haevermans, A. Haevermans \& J. Razanatsoa 831 (Holotype: TAN!, Isotypes: K!, MO!, P!).

Paratypes MADAGASCAR • Varifoana, près d'Ambohimahasoa-sud, 15 May 1964, R. Capuron 26014SF (P02234597!) • Soanierana-Antasibe[Andasibe], $350 \mathrm{~m}$ elev., 10 December 1938, H.J. Lam \& A.D.J. Meeuse 5867 (L-WAG.1111450!, L-WAG.1111451!, L-WAG.1111452!, L-WAG.1111453!, L-L.1477714!, L-L.1477715!).

Diagnosis Similar to Ravenala madagascariensis but differs in its non-suckering habit, much larger dimensions, very thick leathery laminae, very waxy dark green-yellowish petioles, much larger bracts and overall dimensions, whitish/pure white perianth, strong reddish-pink stripes on its bracteoles, cylindrical stigma without basal constriction, stamens much shorter than perianth, and fruit with a truncated apex.

Distribution Eastern rainforests at around 200-500 m elevation in Madagascar ${ }^{13,20}$.

Preliminary IUCN assessments We propose a Data Deficient status for R. grandis; further fieldwork is required to understand its precise distribution and the status of its populations ${ }^{33}$.

Ecology This species seems to favor growing in low discontinuous forests on inselbergs ${ }^{12}$ and thrives in secondary degraded vegetation on the slopes of eastern rain forests.

Etymology The name of this species is in reference to its stature and habit, the most robust species of Ravenala known.

Description Plants solitary (never suckering), 20-30 meters tall (adult), trunk circumference (d.b.h.) 30 $\mathrm{cm}$, juvenile and adult laminae distributed in a perfect fan, 15-30 leaves simultaneously alive on the adult plant, usually 3 leaves between inflorescences. Leaves adult petiole 390-440 cm long, dark green/light green-yellowish, very waxy (Fig. 3c), sheath margin moderately developed to undeveloped (0-9 mm), entire on young leaves, splitting and dryish when old, petiole/lamina ratio 1.8-(2.2)-2.6, adult lamina 170-230 $\times 94-120 \mathrm{~cm}$, light green, juvenile lamina base non-decurrent. Inflorescences 4-6 live lateral inflorescences at a time, $100-120 \times 80-100 \mathrm{~cm}$ (peduncle excluded), 10-20 bracts per inflorescence, bracts 440-540 $\times 140-170 \mathrm{~mm}$, some waxiness (Fig. 4c), margin color uniformly green, cincinnii of $c a$. 20 flowers per bract, flowering sequentially, bracteoles with a strong reddish-pink stripe. Flowers $300 \mathrm{~mm}$ long (ovary included), inferior ovary 50-70 $\mathrm{mm}$ long, perianth whitish/pure white, sepals narrowly triangular 220-240 × 10-15 mm, sheathing (fused) petals narrowly triangular 210-220 $\times 10-12 \mathrm{~mm}$, free petal acicular $150-170 \times 3 \mathrm{~mm}$, slightly smaller than the rest of the perianth with a mean 
free petal / mean fused petal length ratio $=0.8$, petal blotches absent, stamens much shorter than the perianth, 180-200 mm long, style 180-210 mm long, stigma 14-16 mm long, oblong without basal constriction (almost indistinguishable from style). Infructescences lax (bract bases not imbricate at some stages of maturity), stiff and coriaceous persisting bracts on mature infructescence, old infructescences deciduous, 5-18 fruits per bract. Fruits 100-120 × 35-40 mm, trilocular septifragal capsule, apices truncate (Fig. 2c), seeds shiny, dark brown, mostly globose, varying in shape according to their distribution in the capsule, ultramarine blue aril.

Note The leaves of this species are the most robust and tough of all Ravenala species, with a thick leathery texture, making it the material of choice for building roofs ${ }^{35}$.

Ravenala hladikorum Haev., Razanats., V. Jeannoda \& P. Blanc sp. nov. - Figs. 2f, 3f, 4f, $5 f$. Type MADAGASCAR • Andasibe; $18^{\circ} 56^{\prime} 00^{\prime \prime S}$, 48²5'06"E; $940 \mathrm{~m}$ elev.; 05 February 2004; A. Hladik \& C.-M. Hladik 6842 (Holotype: TAN!, Isotype: P!). Paratypes. MADAGASCAR • Andasibe; $18^{\circ} 56^{\prime} 00^{\prime \prime} \mathrm{S}, 48^{\circ} 25^{\prime} 06^{\prime \prime} \mathrm{E}$; $940 \mathrm{~m}$ elev.; 23 August 1998; A. Hladik \& al. 6240 (fruit with seeds: P!). • Andasibe-Mantadia area, Vakôna, Kalonora; 1853'17.3"S, 48²5'51.3"E; 934 m elev., 08 November 2018; T. Haevermans \& al. 833 (TAN!, P!, K!, MO!).

Diagnosis Similar to Ravenala madagascariensis but differs in its non-suckering habit, the alternate positioning of its adult laminae, its dark green leaves, non-waxy petioles with their very papyraceous petiole sheath margins, more than $1 \mathrm{~cm}$ long, smaller lamina dimensions, smaller number of simultaneously live inflorescences, purple stripe on bracts and on bracteoles, non-waxy inflorescences, smaller inflorescences, dense infructescences, truncated fruit apices, and short flowering period from November to December.

Distribution Andasibe, Mantady, Ranomafana ${ }^{21}$. Restricted to Madagascar.

Preliminary IUCN assessments We propose a Data Deficient status for R. hladikorum; further fieldwork is required to understand its precise distribution and the status of its populations ${ }^{33}$.

Ecology High-elevation species found in eastern rainforests at elevations between 600 and $1100 \mathrm{~m}$. The species seems to favor cool tropical humid and shady conditions.

Etymology This species is named in honor of Annette and Claude-Marcel Hladik from the Muséum National d'Histoire Naturelle in Paris, who dedicated their lives to the study of Madagascan biodiversity and contributed greatly to the discovery of this species.

Description Plants solitary (never suckering), 10-15 meters tall (adult), trunk circumference (d.b.h.) 20-30 $\mathrm{cm}$, juvenile laminae distributed like a fan, adult laminae arranged in an irregular fan, 9-18 leaves simultaneously alive on the adult plant, 1-3 leaves between inflorescences. Leaves adult petiole 280-440 cm long, greenish-yellow, not waxy (Fig. 3f), sheath margin very developed (10 $\mathrm{mm}$ and more), split, very papyraceous with min. $1 \mathrm{~cm}$ brown dry expansions, petiole/lamina ratio 2.1-(2.42)-2.8, adult lamina 120-160 × 102-116 cm, dark green, juvenile lamina base non-decurrent. Inflorescences 2-3 live lateral inflorescences at a time, $60 \times 90 \mathrm{~cm}$ (peduncle excluded), 4-7 bracts per inflorescence, bracts 150-510 $\times 64-100 \mathrm{~mm}$, no waxiness (Fig. 4f), margin green with a purple stripe, cincinnii of 5-14 flowers per bract, sequentially flowering, bracteoles with a dark purple colored stripe. Flowers 240-320 mm long (ovary included), inferior ovary 40-60 mm long, perianth whitish, sepals nar-

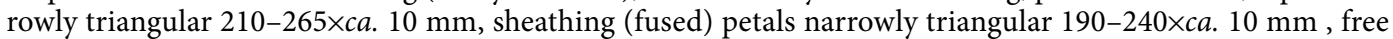
petal acicular 135-220 $\times 5 \mathrm{~mm}$, almost the same size as the fused petals with a mean free petal / mean fused petal length ratio $=0.9$, petal blotches unknown, stamens (roughly) the same size as the perianth, $170-230 \mathrm{~mm}$ long, style 187-250 mm long, stigma 20-25 mm long, ovoid with a basal constriction. Infructescences compact (bract bases imbricate at all stages of maturity), stiff and coriaceous persistent bracts on mature infructescences, old infructescences deciduous, 5-14 fruits per bract. Fruits $82-108 \times 34-48 \mathrm{~mm}$, trilocular septifragal capsule, apices truncate (Fig. 2f), seeds 4-9 $\times 3-6 \mathrm{~mm}$, shiny, dark brown, mostly globose, varying in shape according to their distribution in the capsule, ultramarine blue aril.

Ravenala menahirana Haev. \& Razanats. sp. nov._Figs. 2e, 3e, 4e, 5e. Type MADAGASCAR • Foulpointe, Analalava Forest; $17^{\circ} 42.3^{\prime} \mathrm{S}, 4^{\circ} 27.38^{\prime} \mathrm{E} ; 50 \mathrm{~m}$ elev.; 20 March 2016; T.Haevermans, M. Vorontsova, S. Dransfield \& J. Razanatsoa 826 (Holotype: TAN!, Isotypes: P!, K !, MO!).

Diagnosis Similar to Ravenala madagascariensis but differs in its non-suckering habit, the alternate dark green laminae tending not to form a perfect fan (Fig. 5e), dark red petioles with a zigzagging well developed dryish sheath margin, more strongly obovoid laminae, smaller number of simultaneously live inflorescences, smaller inflorescences tinged with red, pure white/whitish perianth, smaller flowers, dense infructescences, the fruit apices truncate with a mucro, and subequal free and fused petals.

Distribution Appears to be restricted to the east coast in the area around Analalava-Foulpointe up to the Mananara-Avaratra area. Two human observations from Marojejy (North-East) and Tampolo (Masoala) seem also to be this species. Restricted to Madagascar.

Preliminary IUCN assessments We propose a Data Deficient status for R. menahirana; further fieldwork is required to understand its precise distribution and the status of its populations ${ }^{33}$.

Ecology This coastal forest-dwelling species favors low-elevation tropical humid conditions in the AnalalavaFoulpointe area, extending north to Mananara-Avaratra area, and maybe up to Marojejy.

Etymology The name of this species is in reference to one of its local names "menahirana", given to the species in the Analalava-Foulpointe area and meaning "red ravenala".

Description Plants solitary (never suckering), 6-10 meters tall (adult), trunk circumference (d.b.h.) 20-30 $\mathrm{cm}$, juvenile laminae distributed like a fan, adult laminae arranged in an irregular to regular fan, 12-18 leaves simultaneously alive on the adult plant, 3 leaves between inflorescences. Leaves adult petiole $200-230 \mathrm{~cm}$ long, dark red, slightly to very waxy, sheath margin very developed (10 $\mathrm{mm}$ and more), red, entire, forming a three dimensional zigzag pattern (Fig. 3e), then splitting and drying on old leaves, petiole/lamina ratio 1.4-(1.7)-1.9, adult lamina $350 \times 120 \mathrm{~cm}$, lamina color dark green, juvenile lamina base non-decurrent. Inflorescences 1-2 live 
lateral inflorescences at a time, $60 \times 70 \mathrm{~cm}$ (peduncle excluded), 10-12 bracts per inflorescence, bracts 260-360 $\times 50-80 \mathrm{~mm}$, very waxy (Fig. $4 \mathrm{e}$ ), margin color uniformly reddish-green, cincinnii of 8-12 flowers per bract, flowering sequentially, no colored stripe on bracteoles (apices sometimes suffused with pink). Flowers 220-250 $\mathrm{mm}$ long (ovary included), inferior ovary $40-60 \mathrm{~mm}$ long, perianth pure white to whitish, sepals narrowly triangular $180-230 \times 12-16 \mathrm{~mm}$, sheathing (fused) petals narrowly triangular $160-180 \times 5 \mathrm{~mm}$, free petal acicular $160-170 \times 5 \mathrm{~mm}$, free petal the same size as the remaining perianth with a mean free petal / mean fused petal length ratio $=1.0$, petal blotches absent, stamens the same size (roughly) as the perianth, stamen $150-160 \mathrm{~mm}$ long, style 150-200 mm long, stigma $10 \mathrm{~mm}$ long, oblong with a basal constriction. Infructescences compact (bract bases imbricate at all stages of maturity), stiff and coriaceous persisting bracts on mature infructescences, old infructescences deciduous, 8-12 fruits per bract. Fruits $80-100 \times 30-35 \mathrm{~mm}$, trilocular septifragal capsule, apices truncate with a mucro (Fig. 2e), seeds shiny, dark brown, mostly globose, varying in shape according to their distribution in the capsule, ultramarine blue aril.

Note This species is similar to R. hladikorum but is easily distinguished by, in addition to its petioles and its ecology, its truncate mucronate fruit apices, the shape of the synflorescence bracts and the absence of a red stripe on the cyme bracteoles.

Identification key to the species of genus Ravenala.

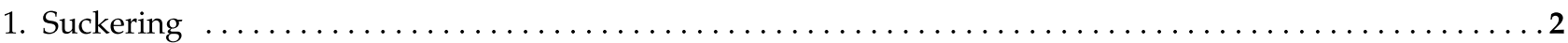

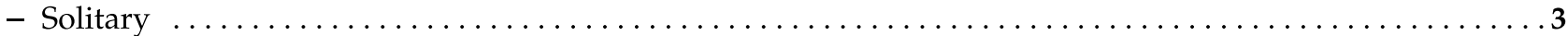

2. Petiole uniformly yellowish-green, petiole wing slightly developed, free petal same size as fused petals

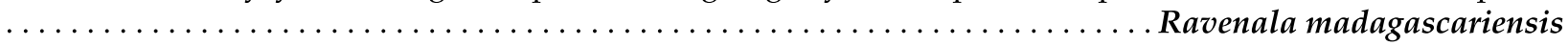

- Petiole tricolor (waxy white, green, reddish/dry), petiole wing developed and dry, free petal much smaller than

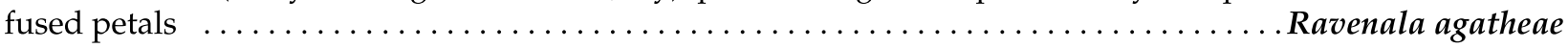

3. Petiole dark red, petiole wing with a dark red zigzag $\ldots \ldots \ldots \ldots \ldots \ldots \ldots$ Ravenala menahirana

- Petiole green or yellowish green, petiole wing developed or absent $\ldots \ldots \ldots \ldots \ldots \ldots \ldots \ldots \ldots \ldots$

4. Very developed papyraceous and deeply split petiole wing $\ldots \ldots \ldots \ldots \ldots \ldots$ Ravenala hladikorum

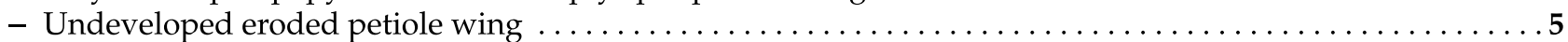

5. Non-waxy petiole, thin non-leathery lamina, plant with small stature, conical fruit apex ... Ravenala blancii

- Very waxy petiole, thick leathery lamina, very large and robust plant, truncate fruit apex ... Ravenala grandis

\section{Discussion}

The five new species described in this paper can be easily identified at both young and adult stages from distinctive morphological characters defined from petiole sheath margins, petiole coloring and morphology, suckering or solitary habits and flower and fruit traits. The main stable character distinguishing these species ${ }^{13}$ is the ability to produce suckers ( $R$. agatheae, $R$. madagascariensis) like other members of Zingiberales, or its absence (i.e. strictly monopodial) ( $R$. blancii, $R$. grandis, $R$. hladikorum, $R$. menahirana) (Table 1 ). The laminae arrangement in space is also of taxonomic significance, especially for the juvenile $R$. blancii, whose leaves, although distichally inserted, have laminae distributed in such a way as to form a torus (Fig. 7b), which is likely to be an adaptation to the low light intensity of the forest floor where it germinates ${ }^{12}$. At early stages, this species, with its decurrent laminae arranged in a torus, bears a striking resemblance to the bird's nest fern (Asplenium nidus Linnaeus ${ }^{36}$ ). The genus occurs across a variety of bioclimates and habitats, with each species seemingly favoring a specific niche. Both suckering species occur at sea level and on low-elevation coastal hills, with the well-known $R$. madagascariensis being documented in the coastal marshes of the east coast of the island, whereas $R$. agatheae is documented in the north-western part of the island (Fig. 1). The comparatively drier climates in which the latter occurs may favor the persistence on the "trunk" of a blanket of dry petioles and infructescences which may be involved in some form of fire resistance. By contrast, the solitary species are all distributed on the eastern part of Madagascar from sea level to around $1000 \mathrm{~m}$ elevation, on slopes originally covered by forests. Their distribution likely follows an elevation gradient, with $R$. menahirana found in now rare sea level coastal forests, $R$. grandis in mid-elevation (300-500 m) forests on steep inselbergs slopes (see Figs. 2, 3, and 4 in Blanc et al. ${ }^{12}$ ), while $R$. blancii and $R$. hladikorum are found in sympatry in the shade in high elevation $(1000 \mathrm{~m})$ rain forests ${ }^{12}$. Further research on the population genetics, pollination and seed dispersal of the formerly monotypic Ravenala would be essential within this new six-species framework. This genus may also prove to be a good model for studying sympatric speciation and provide a better understanding of the interactions of the endemic fauna of Madagascar with this flagship taxon.

\section{Methods}

Taxonomic treatment follows the International Code of Nomenclature (ICN) for algae, fungi and plants ${ }^{37}$ (Shenzhen Code). Specimen citations follow the CETAF (Consortium of European Taxonomic Facilities) guidelines ${ }^{38}$. Specimens were deposited in natural history collections as indicated by their international acronym ${ }^{39}$. Descriptive terms follow standard botanical terminology ${ }^{40}$. Macromorphological characters (see a summary in Table 1) 


\begin{tabular}{|c|c|c|c|c|c|c|}
\hline & R. agatheae & R. blancii & R. grandis & R. hladikorum & R. madagascariensis & R. menahirana \\
\hline Habit & Suckering & Solitary & Solitary & Solitary & Suckering & Solitary \\
\hline Adult dimensions (m) & $6-10$ & $10-15$ & $20-30$ & $10-15$ & $6-12$ & $6-10$ \\
\hline Leaves lamina color & Dark green & Dark green & Light green & Dark green & Light green & Dark green \\
\hline $\begin{array}{l}\text { Leaves simultaneously } \\
\text { alive }\end{array}$ & $9-22$ & $9-16$ & $15-30$ & $9-18$ & $14-26$ & $12-18$ \\
\hline Petiole color & $\begin{array}{l}\text { Tricolor (white, green, } \\
\text { red) }\end{array}$ & Green & Dark green/Yellowish & Greenish-yellow & Yellowish green & Dark red \\
\hline Sheath margin dvp. & $\begin{array}{l}\text { Very developed (10 } \\
\mathrm{mm}+\text { ) }\end{array}$ & Undeveloped & Developped $(0-9 \mathrm{~mm})$ & $\begin{array}{l}\text { Very developed (10 } \\
\mathrm{mm}+\text { ) }\end{array}$ & Developed (0-9 mm) & $\begin{array}{l}\text { Very developed (10 } \\
\mathrm{mm}+\text { ) }\end{array}$ \\
\hline Sheath margin shape & Dryish papyraceous & Eroded & Entire/split & $\begin{array}{l}\text { Brown papyraceous, } \\
\text { split }\end{array}$ & Not dry, entire/split & Dark red dry zigzag \\
\hline $\begin{array}{l}\text { Petiole \& dry infr. } \\
\text { persistence }\end{array}$ & Yes & No & No & No & No & No \\
\hline Juvenile lamina & Non-decurrent & Decurrent & Non-decurrent & Non-decurrent & Non-decurrent & Non-decurrent \\
\hline $\begin{array}{l}\text { Juvenile lamina distribu- } \\
\text { tion }\end{array}$ & Irregular fan & Torus shape & Irregular fan & Irregular fan & Irregular fan & Irregular fan \\
\hline Adult leaves distribution & Regular fan & Regular fan & Regular fan & Irregular fan & Regular fan & Irregular fan \\
\hline Bracts \#/Infl. & $10-14$ & $4-6$ & $10-20$ & $4-7$ & $8-16$ & $10-12$ \\
\hline Bracts L/l & $450-500 \times 80-90(5.3)$ & $160-350 \times 50-90(3.9)$ & \begin{tabular}{|l|}
$440-540 \times 140-170$ \\
$(3.16)$
\end{tabular} & $\begin{array}{l}150-510 \times 140-170 \\
(2.3)\end{array}$ & $200-450 \times 50-100(4.3)$ & $260-360 \times 50-80(4.8)$ \\
\hline Bracts persistence & Siff and coriaceous & Torn and degraded & Siff and coriaceous & Siff and coriaceous & Siff and coriaceous & Siff and coriaceous \\
\hline $\begin{array}{l}\text { Infructescence imbrica- } \\
\text { tion }\end{array}$ & Compact & Compact & Lax & Compact & Lax & Compact \\
\hline $\begin{array}{l}\text { Flower length (+ovary) } \\
\text { in mm }\end{array}$ & $260-310$ & $165-280$ & 300 & $240-320$ & $240-280$ & $220-250$ \\
\hline Free vs fused petals ratio & Much shorter (0.6) & Subequal (1) & Slightly smaller (0.8) & Slightly smaller (0.9) & Slightly smaller $(0.8)$ & Subequal (1) \\
\hline Stamens size vs perianth & Similar & Similar & Much shorter & Similar & Similar & Similar \\
\hline Fruit apex & Conical & Conical & Truncated & Truncated & Conical & $\begin{array}{l}\text { Truncated with bony } \\
\text { mucro }\end{array}$ \\
\hline
\end{tabular}

Table 1. Comparison of the main distinctive morphological characters for the six species of Ravenala.

were studied in the field and in the laboratory from specimens the authors collected, according to national and international standards and regulation, and from specimens held in several herbaria where Ravenala specimens are deposited (G, K, MO, P, TAN, US) ${ }^{39}$. The distribution maps (Fig. 1) were prepared with the software R, using coordinates from our own collections and observation data, from other available specimens ( $n=19$ gatherings, represented as $n=40$ sheets), as well as from the www.inaturalist.org website observations we managed to identify $(n=83)$. We used the triple equality sign $(\equiv)$ to indicate homotypic synonyms, the equal sign $(=)$ to indicate heterotypic synonyms and the 'en-dash' (-) to indicate invalid names. All protologues of relevant names were consulted to establish the nomenclatural synopsis.

Received: 19 January 2021; Accepted: 25 October 2021

Published online: 09 November 2021

\section{References}

1. Adanson, M. Familles des Plantes, 2 (Vincent, 1763)

2. Cron, G. V., Pirone, C., Bartlett, M., Kress, W. J. \& Specht, C. Phylogenetic relationships and evolution in the Strelitziaceae (Zingiberales). Syst. Bot. 37, 606-619. https://doi.org/10.1600/036364412X648562 (2012).

3. Mabberley, D. J. A note on some adulatory botanical plates distributed by Sir Joseph Banks. Kew Bull. 66, 475-477. https://doi. org/10.1007/s12225-011-9291-y (2011).

4. Endlicher, S. F. L. Prodromus Florae Norfolkicae (Apud Fridericum Beck, 1833).

5. de la Bâthie, H. P. 46e Famille - Musacées [Musaceae] (Gouvernement général de Madagascar et H. Humbert, 1946).

6. Andrianifahanana, M. Contribution à létude Biologique de Ravenala Madagascariensis dans la région de Mananara-Nord. (Mémoire D.E.A./S.B.A. ecologie végétale, Faculté des Sciences de Tananarive, 1992).

7. Jacobs, G. H. \& Deegan, J. F. Diurnality and cone photopigment polymorphism in strepsirrhines: Examination of linkage in Lemur catta. Am. J. Phys. Anthropol. 122, 66-72. https://doi.org/10.1002/ajpa.10309 (2003).

8. Willson, M. F. \& Whelan, C. J. The evolution of fruit color in fleshy-fruited plants. Am. Nat. 136, 790-809. https://doi.org/10.1086/ $285132(1990)$

9. Lord, J. M. \& Marshall, J. Correlations between growth form, habitat, and fruit colour in the New Zealand flora, with reference to frugivory by lizards. N. Zeal. J. Bot. 39, 567-576. https://doi.org/10.1080/0028825X.2001.9512760 (2001).

10. Melin, A. D., Moritz, G. L., Fosbury, R. A. E., Kawamura, S. \& Dominy, N. J. Why aye-ayes see blue. Am. J. Primatol. 74, 185-192. https://doi.org/10.1002/ajp.21996/full (2012).

11. Kress, W. J., Schatz, G. E., Andrianifahanana, M. \& Morland, H. S. Pollination of Ravenala madagascariensis (Strelitziaceae) by lemurs in Madagascar: Evidence for an archaic coevolutionary system?. Am. J. Bot. 81, 542-551. https://doi.org/10.2307/2445728 (1994). 
12. Blanc, P., Hladik, A., Rabenandrianina, N., Robert, J. S. \& Hladik, C. M. Strelitziaceae: The variants of Ravenala in natural and anthropogenic habitats. In The Natural History of Madagascar (eds Goodman, S. M. \& Benstead, J.) 472-476 (The University of Chicago Press, 2003).

13. Blanc, P., Rabenandrianina, N., Hladik, A. \& Hladik, C. M. Les formes sympatriques et allopatriques du genre Ravenala dans les forêts et les milieux de l'Est de Madagascar. Rev. Ecol. 54, 201-224 (1999).

14. Blanc, P., Hladik, A. \& Hladik, C. M. Larbre du voyageur dans toute sa diversité. Hommes \& Plantes 40, 38-47 (2001).

15. Rabenandrianina, T. N. Etudes Morphologiques, Biologiques et Ecologiques des Différentes formes de Ravenala madagascariensis Sonn. dans la Région Orientale Malgache. (Mémoire de diplôme d'etudes approfindies (D.E.A.), Université d’Antananarivo, Faculté des Sciences, 2007).

16. Tomlinson, P. B. Phylogeny of the Scitamineae: Morphological and anatomical considerations. Evolution 16, 192-213 (1962).

17. Horaninow, P. F. Prodromus Monographiae Scitaminearum Vol. 8 (Typis Academiae Caesareae Scientiarum, 1862).

18. Bekele, E. \& Shigeta, M. Phylogenetic relationships between Ensete and Musa species as revealed by the trnT-trnF region of cpDNA. Genet. Resour. Crop Evol. 58, 259-269. https://doi.org/10.1007/s10722-010-9568-2 (2010).

19. Hallé, F. \& Oldeman, R. A. A. Essai sur l'Architecture et la Dynamique de Croissance des Arbres Tropicaux (Masson \& Cie, 1970).

20. Hladik, A. et al. Données sur la répartition géographique du genre Ravenala et son rôle dans la dynamique forestière à Madagascar. In Diversity and Endemism in Madagascar (eds Lourenço, W. R. \& Goodman, S. M.) 93-104 (Mémoires de la Société de Biogéographie de Paris, 2000).

21. Turk, D. Checklist of the vascular plants of Ranomafana. Tech. Rep. (1998).

22. Linnaeus, C. Genera Plantarum Eorumque Characteres Naturales Secundum Numerum, Figuram, Situm, \& Proportionem Omnium Fructificationis Partium. (Suntu Varrentrapii et Wenneri, 1789).

23. Scopoli, G. A. Introductio ad Historiam Naturalem Sistens Genera Lapidum, Plantarum, et Animalium: Hactenus Detecta, Caracteribus Essentialibus Donata, in Tribus Divisa, Subinde ad leges Naturae (Apud Wolfgangum Gerle, 1777).

24. Sonnerat, P. Voyage aux Indes Orientales et à la Chine. Tome Second (Chez l'Auteur, 1782).

25. Dorr, L. J. \& Parkinson, P. G. 1320. Proposal to conserve the spelling Ravenala (Strelitziaceae). Taxon 39, 131-132 (1990).

26. Brummitt, R. K. Report of the committee for Spermatophyta: 39. Taxon 42, 873-879 (1993).

27. Brummitt, R. K. Report of the Committee for Spermatophyta: 37. Taxon 39, 293-296 (1990).

28. Gmelin, J. F. Systema Naturae Per Regna Tria Naturae v. 2 pt. 1 (Impensis Georg. Emanuel. Beer., 1791).

29. Forsyth, W. J. A Botanical Nomenclator: Containing a Systematical Arrangement of the Classes, Orders, Genera, and Species of Plants as Described in the New Edition of Linneeus's Systema Naturce, by Dr. Gmelin, of Gottingen (Printed for T. Cadell, and P. Elmsly, in the strand; and G. Nicol, Pall-Mall., 1794).

30. Willemet, P. R. Herbarium mauritianum. Ann. Bot. 18, 1-66 (1796).

31. von Willdenow, C. L. Species Plantarum. Edition quarta. Tom. 2 Pars. 1 (Impensis G. C. Nauk, 1810).

32. Richard, L. C. M. Urania ravenalia. Novorum Actorum Acad.e Caesareae Leop. Carol. Nat. Curios. 15(suppl.), 19 (1831).

33. IUCN. IUCN Red List Categories and Criteria: Version 3.1, 2nd edn. (IUCN, 2012).

34. Hladik, C. M., Blanc, P. \& Hladik, A. Larbre du voyageur Deuxième partie: Des usages et de la diffusion horticole du Ravenala. Hommes \& Plantes 41, 18-27 (2002).

35. Rakotoarivelo, N. et al. Ethnobotanical and economic value of Ravenala madagascariensis Sonn. In Eastern Madagascar. J. Ethnobiol. Ethnomed. 10, 57. https://doi.org/10.1186/1746-4269-10-57 (2014).

36. Linnaeus, C. Species Plantarum, vol. 2 (Impensis Laurentii Salvii, 1753).

37. Turland, N. J. et al. International Code of Nomenclature for algae, fungi, and plants (Shenzhen Code) adopted by the Nineteenth International Botanical Congress Shenzhen, China, July 2017. Regnum Vegetabile 159 (Koelz Botanical Books, 2018).

38. Bénichou, L., Gérard, I., Laureys, É. \& Price, M. J. Consortium of European Taxonomic Facilities (CETAF) best practices in electronic publishing in taxonomy. Eur. J. Taxon. 1-37, 2018. https://doi.org/10.5852/ejt.2018.475 (2018).

39. Thiers, B. Index Herbariorum: A Gobal Directory of Public Herbaria and Associated Staff. New York Botanical Garden's Virtual Herbarium. http://sweetgum.nybg.org/science/ih/. Accessed 5 Aug 2020 (2020).

40. Beentje, H. The Kew Plant Glossary: An Illustrated Dictionary of Plant Terms 2nd edn. (Royal Botanic Gardens Kew, 2016).

\section{Acknowledgements}

The authors wish to thank Madagascar National Parks Association and KMCC (Kew Madagascar Conservation Centre) for obtaining the collections, import and export permits for the 2016 field expeditions and help with logistics issues for both the 2016 and 2018 field expeditions; the Parc Botanique et Zoologique de Tsimbazaza in Antananarivo and the Missouri Botanical Garden Antananarivo Office for logistic support; the Franklinia Foundation for funding part of the fieldwork for the Flore de Madagascar project; curators of the various international herbaria visited (G, K, MO, NY, P, TAN, US); Mrs Mag Izouard and her staff from the Vakôna resort, who facilitated our research on site for Ravenala blancii and R. hladikorum. the French travel agency Nomade Aventure, who co-sponsored the 2018 field expedition, in partnership with the Société des Explorateurs Français, of which A.H. and T.H. are members.

\section{Author contributions}

All authors conceived the experiment. All authors conducted the field expeditions. All authors analyzed the results and wrote the descriptions. A.H. prepared the drawing in Figures 2, 6 and 7. All authors reviewed and commented the manuscript.

\section{Competing interests}

The authors declare no competing interests.

\section{Additional information}

Correspondence and requests for materials should be addressed to T.H.

Reprints and permissions information is available at www.nature.com/reprints.

Publisher's note Springer Nature remains neutral with regard to jurisdictional claims in published maps and institutional affiliations. 
(c) (i) Open Access This article is licensed under a Creative Commons Attribution 4.0 International cc) License, which permits use, sharing, adaptation, distribution and reproduction in any medium or format, as long as you give appropriate credit to the original author(s) and the source, provide a link to the Creative Commons licence, and indicate if changes were made. The images or other third party material in this article are included in the article's Creative Commons licence, unless indicated otherwise in a credit line to the material. If material is not included in the article's Creative Commons licence and your intended use is not permitted by statutory regulation or exceeds the permitted use, you will need to obtain permission directly from the copyright holder. To view a copy of this licence, visit http://creativecommons.org/licenses/by/4.0/.

(C) The Author(s) 2021 